\section{Marketing Focused on The Online Brand Community - The Example of Zara}

\author{
Nevenka Popović Šević, Anja Jeremić,
} Milica Slijepčević, Milena Ilić

JEL classification: M31, M21

\section{INTRODUCTION}

The modern business environment greatly influences the pace at which marketing discipline is developing, which is a challenge for companies competing for global consumers. With the development of the Internet as the main channel for the implementation of optimal marketing models, Internet marketing constantly improves as a new area of marketing theory and practice. Consumers are in a situation where they can share their experiences with products and companies. On the other hand, the power and attractiveness of the Internet environment have also transformed the way consumers behave, thus creating the new patterns that must be taken into account when creating appropriate marketing strategie svery different from traditional ones. In this way, online marketing has become a completely new discipline today compared to what it was known to be before, thus making traditional marketing methods less effective and expensive (Kotler \& Keller, 2011); (Jaworski, 2018). Internet networking is becoming a competitive game with traditional media in terms of consumer attention and focus, and in terms of how to seek information before making the final purchase decision. For this reason, it is important to know and keep pace with all changes made in Internet marketing, given the fact that there is a completely new terminology associated with the various approaches and strategies based on the Internet that are crucial for gaining sustainable competitive advantage (Heinonem, 2011).

Classical industrial products are often static and can only be changed to a limited extent or any such change is almost excluded. Digitized products include hardware, software and services (Khan, Yang, Shafi\& Yang, 2019; McCorkindale\&Distaso, 2013) and require a multilevel technology infrastructure known as a "technology architecture", which allows data exchange between users, products, companies' systems, external sources and other products through superior services. In this way, the technological architecture serves as the basis for the service architecture layer. The lifecycle of digitized products is extended by the acquisition and decommissioning of services. Therefore, it is possible to create digitized products and services step by step. Digitized products and services support the joint creation of value together with the customer and other stake-
Abstract: Nowadays, expansion in the technological achievements domain is increasingly faster and big changes have been made in people's interconnectedness and communication with the introduction of the Internet in our everyday lives. People started connecting online. Online communities have emerged as a network of the people gathered around the same interests, no matter whether such interests are private or business interests, through specific online media, thus creating a vast platform for the exchange of information, experiences and knowledge that transcends all geographical, social and temporal barriers. As a new information exchange platform, online communities also represent a new channel through which companies promote their business and their products, and provide new points of contact with their customers, who have increasingly greater power, the availability of and access to information. Marketing aimed at online consumer communities is analyzed in the paper on the example of Zara.

Keywords: online brand community, consumer behavior, social media, fashion brand, Zara. 
holders, such as independent development networks, in various ways. It is especially important in the process of branding, i.e. positioning a brand in sub-proponents' minds (Slijepcevic, 2019). First, there is a constant opportunity for feedback from the customer to the supplier of the product. The Internet connection of the digitized product enables the permanent collection of data on the use of the product by the customer. Second, the data provided by a large number of digitized products may generate new insights, otherwise impossible with data from a single device, which in turn may generate indications for the development of new services.

Advances in digital and manufacturing technology now allow brands to offer customers the ability to personalize or customize products online or in-store, and then deliver them quickly. The advantage of customization is that it further strengthens the user experience for the customer by inviting him/her to become a partner in the product creation process. The better the user experience, the better the conversion opportunity (Ramaswamy\&Ozcan, 2016; Zablocki, Schlegelmilch\&Schant 2017). Digital communications are an area in which the rapid and frequent changes that lead to shortening communication between the sender and the recipient of a message are made, which speeds up the communication process and makes it more complex (Slijepcevic, Radojevic\&Peric, 2020). Digital space also enables the collection of the data that, when analyzed, enable brands to continuously improve the user experience. Now, brands need to bring the power of digital space into the retail space in order to benefit from an increasing trend towards mobile search and prepare for possible further changes. Online promotions, product displays, device configurations, store layouts, and staff interactions must work together.

\section{LITERATURE REVIEW}

Customers' voices and opinions in the past were not so strong and brand managers had the luxury of ignoring them. Brand managers played the key role in creating brand-related stories, whereas today, consumer-generated brand stories on online forums have been attracting greater attention and going viral. Therefore, it is understandable that a company's production program must not be static. It is necessary, however, to monitor consumers, the competition and the market (Veljković\&Panić, 2017). Internal marketing is also important for creating an organization's brand both internally and externally in order to encourage a two- way communication (Bogićević Milikić\&Ognjanov, 2019), especially in the digital world.

Digitization is revolutionizing customer behavior. Accordingly, consumer industries need to act quickly so as to meet digital consumers' expectations. Also, digital innovations affect consumer industries: shifting power from brands to consumers, shifting values from traditional to digital participants, and involving consumers in the process (Gautam\& Sharma, 2017). Besides, the functions such as providing information, advice and guidance, as well as order processing within a common and interactive shopping tool, are considered as important factors in building trust in e-commerce compared to traditional sales (Margarida, Gamboa\& Martins, 2014; Huseynov, Huseynov\&Ozkan, 2014). The proper understanding of consumers in the online regime and the purchase process is extremely important, because it is helpful to managers in decision-making andthe creation of the cognitive basis by carrying out consumer analysis, helps legislators enact laws related to the purchase and sale of goods and services, ultimately helping consumers make better decisions. In order to adapt a service to the user, it is necessary to know the user's needs, desires and affinities andgenerate additional benefits for and a greater satisfaction of the target public as well (Veljković, 2018).

The consumer is faced with a lot of purchase decisions almost every day. The largest number of the companies that do research in consumer purchase behavior try to find good answers to the question of what consumers buy, the number of purchases and the purchasing method, the places they go to in order to make a purchase and the reason for making a purchase. Marketing professionals can look for answers to the type of consumers' purchases, amounts and places of purchase through research and by conducting studies, but it is not so simple to determine the reasons for consumer or customer behavior (Schlegelmilch, 2016; Van Roy, Rossetti \&Piculescu, 2015). Unanimous marketing communication through global integration assumes the synchronization ofthe entire marketing campaign which is ultimately aimed at conveying a consistent message to the target public in different geographic markets and providing a unique brand positioning as well (Ognjanov, 2013).

Numerous researchers have addressed the brand identity creation issue via an online brand community (Black \&Veloutsou, 2017); (Kornum, Gyrd-Jones, Al Zagir\& Brandis, 2017). Brand communities are a special type of the social cohesions that share the co-created culture of communication, meanings, 
rituals and practices (Merz, He \&Vargo, 2009). The members of each brand community are the fans and faithful followers of a given brand who are ready to spread their aspiration to the brand and their brand orientation even beyond the mentioned community. In the context of the online brand communities where members play an active role, both the members of the brand community and companies have overall benefits in addition to consumers (Gyrd-Jones \& Kornum, 2013). Together with the members of the online brand community, companies tailor and shape the brand identity, while consumers are motivated to participate in online brand communities because they have a unique opportunity to strengthen their own opinion and identity (fulfilment), and learn and share value through a particular brand, too. It is important for online brand communities to be relevant, have a continuous flow of communication with consumers, have frequent posts and be highly interactive and able to render a service with a rich database at a given moment (Kozinets, 2015).

\section{SOCIAL MEDIA MARKETING ACTIVITIES}

Blogs, photo-sharing websites and social networking websites have allowed peers to share their thoughts, messages, information, images, and videos. Social media are divided as follows (Jaworski, 2018): social networks to connect; media exchange networks sharing photos, videos and other media; discussion forums; content maintenance tags and nets; consumer screening networks; blogging and publishing networks; interest-based networks; social purchasing networks; sharing economic networks, and anonymous social networks. Social networks enable a far more diversified communication - they strengthen consumers' desire to communicate both with each other and with the company's product (Dabrowski\&Schivinski, 2016). A company's presence on social networks also enables both the initial information about the company's product and feedback from consumers. In this way, consumers are listened to more efficiently and are easier to interact with (Karamian, Nadoushan\&Nadoushan, 2015). The use of social networks such as Facebook, LinkedIn, YouTube and Twitter has long since reached all fashion brands and has become a significant marketing tool in communicating with consumers. This type of superior technology is already showing its considerable advantage, while consumers are simultaneously building their re- lationships through these same social networks (Gautam\& Sharma, 2017). It is interesting to note that applications within social networks grow in number day by day. About two-thirds of all the Internet users are also believed to be the users of social networks (Jung, 2017). The online presence of fashion brands on various social networks provides a magnificent platform for consumers in terms of numerous associations and interactions with a company's brand as well (Dahana, Miwa \&Morisada, 2019). Social networks are a unique platform for performing promotional activities of all forms of modern business in order to attract consumers (Popp \&Woratschek, 2016).

Recently conducted research studies have provided the evidence that consumer engagement remains a problem for social media users. Numerous factors contribute to this claim. First, social media are a relatively new marketing phenomenon and that is the reason why there is a naivety about how to create, monitor and measure engagement. Second, with many different formats and platforms, social media have become fragmented media, which makes it more difficult for companies to monitor and coordinate them. Along with the saturation of content across all channels, said fragmentation has imposed greater cognitive demands on consumers, forcing them to either ignore content or become more selective of what they view and process. In their search for short-term sales profits, retailers rely on social media too much in order to provide consumers with sales promotions, which continues to exert a negative influence on the brand equity. The literature review reveals the five categories of consumer engagement predecessors: brand factors, product factors, consumer factors, content factors and social media factors (Ramaswamy\&Ozcan, 2016).

The branded content that consumers may engage with clearly shapes the extent to which consumers are engaged. The relationship with the content is the primary factor that influences the behavior of social sharing. The ECA is likely to engage consumers on the posts that are not too commercial and involve emotions. The format and purpose of content also influence consumer engagement. Posts with pictures receive more likes, comments and sharing. Consumers will prefer task-oriented content rather than self-directed content. They are more likely to share the entertaining and educational content generated by users and the quality of the product is unimportant. Also, consumers preferably post information about interesting products and brands. This is due to the two factors: consumers have more time to construct messages while writing in comparison with the situation 
when they are speaking, and self-improvement is the key motive when posting messages about products and brands. There are four attributes of social networks that promote engagement: social relationships, entertainment, access to information and ease of use.

\section{ONLINE BRAND COMMUNITIES}

Brands and their dedicated customers form a unique community. Investment comes in the form of emotional connections created when customers invest their money, time and interest in something surpassing a purchase itself. No matter how they are established, the purpose of these connections is to build the relationships that will form a community of brands. They enable long-term, sustainable growth based on repeat purchases from high-value customers. It is necessary to determine the difference between the companies that only have a recognizable brand, on the one hand, and strong brand communities, on the other (Zablocki et al., 2017).

One of very important processes in online brand communities creation is the so-called "bridging", which refers to the management of the different meanings of the brand identity in communication with community members (Edvardsson, Tronvoll\& Gruber, 2011). Bridging presupposes the negotiation of the company brand itself, its values and, finally, its identity. It is the communication of the basic values of the brand with the members of the online brand community that is the critical activity implying continuous communication between the company and the admirer of the given brand.

Through a partnership between the both parties that create the online brand community, consumers are invited to participate in the development of new products, and there is a wish to hear each of their designed contributions that will lead to better partnerships and, consequently, brand strengthening (GyrdJones \&Kornum, 2013). Through the empowerment of customer-generated content, various values (such as positive reactions from the public opinion) again reach online brand communities, thus strengthening the legitimacy of the given brand (Hakala, Niemi\&Kohtamäki, 2017). In this way, a synergy of presenting all the symbolic meanings of the corporate brand identity is achieved, where online brand communities represent an important breakthrough towards communication to a broader consumer market.

When done well, the value of branded communities reflects in the fact that they create a unique space for consumers to express their thoughts, exchange their ideas and educate themselves on the products and services of the brand in a supportive environment. Technology is used to create the environment that facilitates various forms of networking activities (Slijepčević\&Radojević, 2018). Branded communities are not intended to create a need for a product or prolong the feelings like "the brand to the consumer". These communities focus more on what consumers want, whether they approve of or buy the products of the brand (Jaworski, 2018). The attractiveness of virtual communities is that they are derived from anonymity and that there are no regulated behavioral patterns, which makes them very attractive to the companies that perceive them as a new type of targeting (Marić, Kovač Žnideršić, Paskaš, Jevtić\&Kanjuga, 2017).

The purpose of brand communities is to create value for all stakeholders. Value is created by generating and sharing opinions in the form of the content related to the products that are of an interest to the audience. On the other hand, consumers help each other by sharing their experience of using the products offered by brands, which helps others make their purchasing decisions. Personal interaction through these channels may help companies gain an insight into the development of a new product. Even consumers can show their interest in building new products or making changes in an existing product line by submitting their timely reviews and suggestions. This type of engagement and value creation is only possible if consumers find relevant content on the online channels generated by companies. For the mentioned reasons, global companies first increase the participation and number of followers on different digital platforms through numerous offers and then work on strengthening the engagement of their consumers through various activities (Constantinides, 2014).

For a community to be effective, it must have members. Therefore, the most effective brand communities are those that stand out in showing value to the customer. One way to determine this value is to reward a welcome such as account opening points, and members are motivated to engage themselves then. Once members join a community, they have to do something to be considered as active members. After joining and engagement, the communities of the strongest brands use the power of sharing to end the building of the community. The best brand communities consider that a member is essential. The goal is for a member to share content and not only be an avid customer, but an avid brand advocate as well. It is important to show members the value of sharing in order for them to 
stand up for the community. Marketing professionals may do research and conduct studies in order to find answers about the type of the purchase made by a consumer, and the amount and place of such a purchase, but the reasons for consumer or customer behavior are not so simple to determine (Schlegelmilch, 2016).

To conclude, brand managers need to provide an environment of trust, dialogue and the exchange of experiences through online brand communities (Ramaswamy\&Ozcan, 2016), all this in order to make the members of an online brand community feel they are a part of a big family. At the same time, the importance of communicating with consumers outside the online brand community should not be underestimated, either, as this creates overall support for a given brand.

As an imperative of modern business, companies are ordered to constantly coordinate their steps with the fast digital world. User-generated content has overshadowed other marketing trends over the years. Produced and published by users on various online platforms, it is the most authentic, creative and reliable content visible online. Promotion is not done by a brand, but by customers themselves. Everything visible online, including testimonials, reviews, feedback, social media content, blogs, videos, or pictures, is a part of the user's useful content. It is mostly the millennials who produce a huge amount of content through social media and any other online platform on a daily basis. Digital interaction with customers in the field of communication through social networks and the creation of digital content are a kind of the marketing mediation of social media (Tuten\& Mint Wimsatt, 2018). Social media marketing is the key factor for the success of all "born global companies" (Ashley \&Tuten, 2015).

User-created digital content is equivalent to trust. More and more customers have been relying on the brands that display consumer content. As has been mentioned above, online content (such as reviews, images, videos, testimonials, and so on) is a part of user-generated content. Created by users themselves, who depict their life experiences, it is more realistic for other users, which humanizes the brand to a great extent. Only those companies that are veterans in creating international marketing through communication in the form of various social networks will create a recognizable name on a global scale (Singh, Sao, Nagare\&Dharmarajan, 2017). It is evident that the entire marketing world, including the companies that want to successfully operate from within the physical world, has moved to the virtual world. The importance of managerial success is the implication of a quality marketing approach through social networks (Yadav \& Rahman, 2017).

One of the qualities that distinguish the digital content created by the users of the other forms of content is the "human element". Unlike the other forms of content, consumer-generated content builds a direct relationship with customers. Created by users themselves, consumer-generated content humanizes the brand most simply and simultaneously uniquely. Brand humanization not only increases the value of the brand on the market, but it also attracts customers' attention. Through tradition, culture and consumer awareness (the awareness perceived in the members of brand communities), certain norms and rules regarding value issues are created that focus on the shared experience of using a favorite brand. In this way, the expected quality of the brand reduces the perceived risk in terms of time, functional characteristics and money as a consumer's expense, and the prestige that the brand community brings with itself reduces the consumer's psychological risk (Popović Šević, 2019).

By giving a new definition to e-commerce, user-generated social media feeds meet consumer expectations by individually merging the point of inspiration with the point of sale. Known as purchasable content, this customized user-generated content (posts) is (are) labelled by the products that allow customers to purchase products directly from the posts. Purchasable content provides users with a fun and engaging shopping experience. Users can enjoy the benefits such as high informative value and engagement opportunities, a shorter real-time travel, the authenticity and reliability of content, and so on. Brands can use in-store content to increase conversions, build brand trust, increase engagement, provide an exciting shopping experience, and so forth. These posts also encourage the potential engagement of users on an e-commerce website, encouraging them to revisit the e-commerce website for the next shopping session.

User-created digital content implies the creation of creative content. The power of this content has been recognized not only by small brands, but also by the world's biggest companies. User-generated digital content seems to be more cost-effective than TV commercials, billboards, and so on. Many customers share pictures, videos, and reviews on social media so as to share their real experiences with the products and services of a brand. Addressing the audience in a loyal and authentic tone, the digital content created by users communicates the values of the brand in a way that no other advertising content could. In this way, 
companies can build strong and long-term relationships with their customers by recognizing and valuing their customers.

\section{THE ZARA CASE STUDY}

ZARA was founded by Amancio Ortega, who is also the founder of the Spanish INDITEX Group, in 1975. Since October 2019, ZARA has been the leading fashion brand in Spain and one of the three leading brands worldwide (Chunling, 2020). The design cherished by this brand is trendy and the prices are relatively affordable compared to other well-known fashion brands.

Zara is a Spanish fashion brand belonging to the InditexGroup, the biggest and extremely highly popular fashion retail chain. This fashion group owns the Massimo Dutti, Pull and Bear, Bershka, Stradivarius, Oysho, Zara Home and Uterqüe brands. As a company, Zara belongs to the group of born global fast fashion companies. The companies defined in this way are those that achieve their efficiency through competitive advantage in the entire chain of business they perform (from the way stocks are used to the final sales) in the global market (Cheney \&Munshi, 2017). The companies like the Zara fashion brand initially start their business locally in order to expand themselves through their stores throughout the world (Kraus, Niemand, Angelsberger, Mas-Tur \&Roig-Tierno, 2017; Garcia-Lillo, Claver-Cortes, Marco-Lajara\&Ubeda-Garcia, 2017). Zara is recognizable for its successful reproduction of the latest world trends of the most luxurious brands. In this way, its consumers worldwide wear new models, and at far more affordable prices (Berman, 2017).
The Spanish company is the leader in an instant fashion. Zara's success and popularity mainly stem from its ability to provide customers with what they want. Their flexible supply chain and technology-based approach have led to great business results. The company location strategy is an aspect of its business success. Zara currently operates in 2213 stores on 93 markets and on 39 online markets. Zara dare continuously strengthen its store portfolio by closing nonprofit shops, opening new markets and expanding sister-brands on the existing markets (the Zara official Facebook page).

In September 2010, Zara launched its online boutique. The website was launched in Spain, the United Kingdom, Portugal, Italy, Germany and France. In November that same year, Zara Online expanded the service to five more countries: Austria, Ireland, the Netherlands, Belgium and Luxembourg. Its online stores started operating in the United States in 2011, in Russia and Canada in 2013, in Mexico in 2014, in South Korea in 2014, in Romania in 2016, and so forth.

In 2020 , Zara ranked $35^{\text {th }}$ on the same list. The total value of the brand was estimated at 14.862 billion dollars in 2020, whereas its value in 2019 amounted to over 17 billion dollars. So, Zara dropped from the $29^{\text {th }}$ to the $35^{\text {th }}$ place in just one year. Zara is not the only fashion brand to have been recording a negative result in 2020 compared to 2019. The impact of the COVID19 pandemic was negative on the entire global fashion industry, so the brands strongly established and positioned on the global market (such as Zara) have recorded no growth at all over the past year even though they were willing to adapt to change. Zara recorded a loss of $13 \%$ in the brand's value, according to the Interbrands official website.

FigURE 1. The trends of the value of the ZARA brand from 2005 to 2020

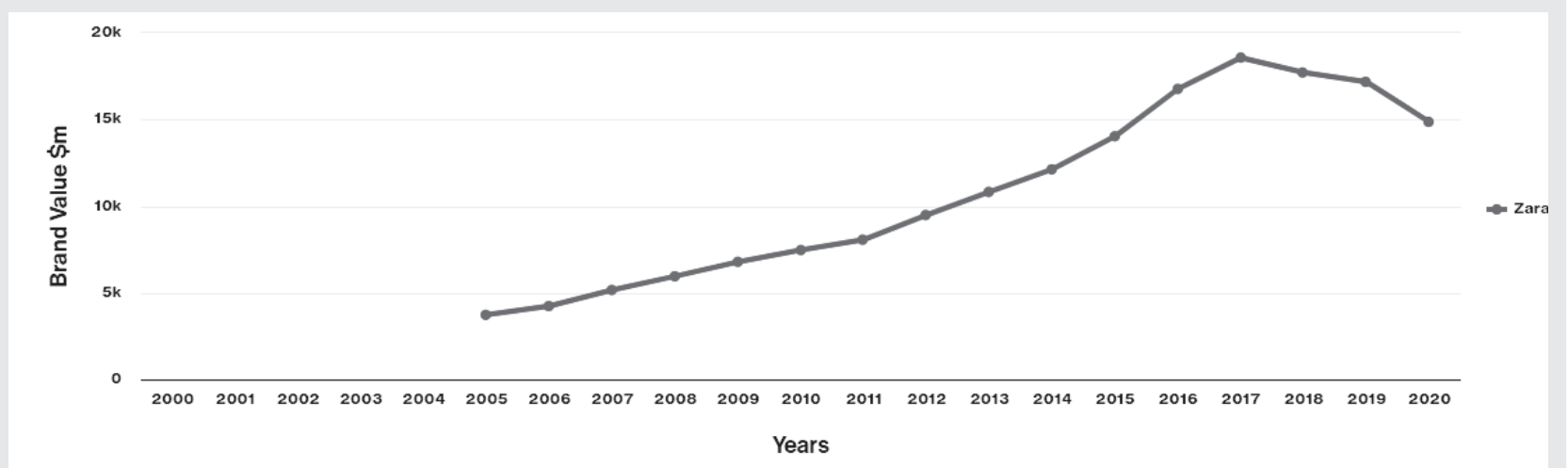

SouRcE: Interbrand official website. Retrieved from https://interbrand.com/best-global-brands/zara/(25.04.2021.) 
Zara has social media profiles on Facebook, Twitter, Instagram, YouTube, Pinterest and LinkedIn. Due to the importance of images and videos in fashion, Instagram and Facebook are their primary social media platforms. On various social networks, Zara publishes the content focused on the products that provide the audience with an insight into the company's latest offers. According to the Facebook demographic data, their follower base mainly consists of young women. Nearly 30 million people love and follow the Zara Official Facebook page (Zara Official Facebook, 2021). Through the Facebook social network, Zara visibly broadcasts its users' trust, their satisfaction and loyalty (Gamboa\&Goncalves, 2014). Zara's Facebook page mostly shows the company's latest collections. Their visual content includes book-style photographs. Not surprisingly, their clothes speak for themselves and trigger the most engagements in terms of likes and sharing.

Facebook and Instagram (i.e. as many as 39 million followers) are considered as the basic social network internet platforms through which this fashion company communicates with its fans and customers. On Instagram, this fashion company monitors its followers' demand via the inquiries submitted by those who would like to look like the models in Zara cuts (Schlossberg, 2015). There is an extremely large number of the companies present with their business on Facebook and achieving global popularity (Tuten\&Mintu-Wimsatt, 2018). However, most of those present in the fashion industry point out the fact that Instagram is the basic consumer communication platform. This was supported by a research study (Abdel Fattah, Galal, Hassan, Elzanfaly\&Tallent, 2017) which indicated that Instagram generated extremely high reaction and sentimental response rates, which is a powerful tool for fashion houses in creating social value through preferred fashion products.

The literature on digital marketing in the fashion industry suggests that social influencers are a critical point when speaking about the creation of subjective perceptions and norms regarding consumer intentions to make the final purchase of a clothing item (Gunawan\&Huarung, 2015). Although many fans of fashion brands follow the blog and actively participate on it, public figures and influencers are becoming a necessary moment of engagement in the overall digital show of a certain fashion brand. Zara took advantage of an interesting approach with its influencers on Instagram. They launched the "Timeless" campaign, which contains models older than 40 . The veterans of the fashion industry participated. This campaign made a great impression on consumers, thus enabling the strengthening of the position on the fashion market. Similar to content, publishing frequency is vital for brand consistency building. Although there is no single approach to the number of posts, consistency is of key importance. Zara manages to remain consistent in its frequency of posting on both Instagram and Facebook at least once a day.

With the art format, it also gave its consumers access through the Pinterest social network followed by almost 1400000 users (Zara Official Pinterest, 2021). This company is also present on the networks such as YouTube and Twitter. Zara also managed to remain relevant by joining the conversation about social causes. These posts attract the most retweets for the brand.

Zara's social media strategy is highly dependent on visual elements. They have a photo-oriented synchronized profile on all social platforms. This kind of the consistency of visual content is vital for brand strengthening. Uniformity maintenance helps consumers know what content they can expect from a brand. In that way, the identity of the brand that interacts with its audience is also cherished. Continuously editing its pages on social networks, regularly changing and updating its images and videos, Zara inspires its consumers in the form of the latest fashion design. Through the Zara People website, the existing consumers and the potential consumers of this fashion brand are asked to post their photos in one of Zara's models and participate in the competition in that way.

As the participation of and interaction between consumers and fans in the online brand community have become extremely popular in the fashion industry (De Valck, Van Bruggen\&Wierenga, 2009), fashion companies' interest in monitoring consumer behavior is understandable.

The research studies shows that Zara company's marketing activities on various social platforms positively affect consumers' purchasing intention. The emphasis is placed on interaction with consumers and deepening loyal relationships with them. ZARA organizes its performance on social networks in two directions -in the direction of its own publicity, and also because of the fun it wants to have with its followers (customers). ZARA selflessly shares its experiences with its customers, spreads the awareness of responsibility on online chats as well. In this way, ZARA skill fully tailors its marketing strategy so as to build the brand personality through social networks, as well as trust in its brand (Mayrhofer\&Roederer, 2016).

One of the recent research studies on the brand associations that consumers have against the fashion 
company ZARA includes the following synonyms: "a recycling fabric", "artificial leather", "the basic color", "the natural style", "diverse items", "stylish", and "sophisticated". Besides, the keywords "expensive" and "long-term clothing" are associated with expensive, long-wearing brands, which in turn lead to "waste reduction." (Kim \&Wha Oh, 2019).

Research in customers and their habits was of great importance for the Zara fashion brand success. They implemented the same strategy on their social media. Zara constantly uses social media to talk to its customers, which in turn managed to maintain brand loyalty. Branded content has become the most important marketing tool today (Blindčević, 2019).

The major aspect of ZARA's success on social media can be attributed to the inclusion of the influence of fashion-focused bloggers. There are several Instagram accounts exclusively dedicated to clothing vendors. Every season, Zara brand products are sold on social networks and their hashtags related to the brand generate millions of results. For Zara, every decision and strategy are related to the customer. The Zara company makes the customer experience royal. The product used to be the king, but no more. In the new retail economy, experience is more important than products.

The formation of a new digital strategy in the COVID-19 crisis is of great importance for the fashion brand Zara. With its primarily offline shopping experience, Zara was hit hard by the global store closures amidst the COVID-19 crisis in 2020, when sales in fell $44 \%$ year-over-year in the first quarter 2020 . The company reported a net loss of $\$ 482$ million. Inditex announced it would close between 1000 and 1200 stores worldwide, focusing on the retail stores in Asia and in Europe. Although online sales were encouraging (Zara's online sales increased by $50 \%$ for the first quarter 2020), that was insufficient to mitigate the damage. As of the last days of December, however, the stores were not closed, not even in Serbia, although the closing was announced (the Inditex official website).

Amancio Ortega plans to spend \$ 1.1 billion to expand its digital strategy and networking capabilities by 2022 , and the additional $\$ 2$ billion in stores so as to improve the integration between the online and the offline environments for faster delivery and real-time product tracking. Its goal is for online sales to account for at least $25 \%$ of the total sales. To achieve this goal, Zara will have to devise new ways to digitally engage its customers not only through its online store, but through online communities and social media as well (Chunling, 2020).
The fashion brand Zara realized the potentials of mobile trade late and quickly had to catch up with competitors. The results of the market analysis point to a scenario in which spending on mobile commerce will threaten e-commerce by 2021 . On average, most brands currently generate about $15-20 \%$ of the traffic on their websites via mobile devices. Zara should make mobile shopping not only an effortless experience, but also a wonderful experience. Making a brand experience meaningful and exchange valuable, Zara exploits the potential of its customers to promote the brand. Instead of suppressing marketing, Zara attracts customers and perceives them as influential brand promoters, all this with the aim of improving its business, services and products, and encouraging them to dissipate the recommendation for the brand.

Great loyalty and brand loyalty are recorded: Consumers are simultaneously becoming the brand promoters who share the excitement over the brand with their networks. Zara has the highly developed data infrastructure that enables an efficient analysis of what is sold and spoken about on social media platforms. This data is used to improve business aspects ranging from a product offer to a service improvement. The two-way communication between the customer and the fashion brand Zara enables a continuous improvement of products and services.

\section{CONCLUSION}

Following trends, innovations and the new patterns of competitors' and customers' behavior have become an important part of the process of the creation of a recognizable competitive advantage and reaching target customer segments in the digital time. The virtual world provides a lot of room for improvement, creative strategic approaches and top performance. On the example of the fashion brand Zara, it is possible to understand that every brand needs a good marketing strategy on social networks in order for that brand to be able to grow and remain sustainable in today's business environment.

The Zara company is focused on their customersit is capable of understanding, anticipating and meeting preferences for contemporary fashion trends at affordable prices, too. In addition to the efficient supply chain, the brand's ability to create a design for its customers is unique and gives it a competitive advantage. Most fashion trends often start unexpectedly. One of the secrets of Zara's global success is its culture and respect for the fact that there is no better and more au- 
thentic trend initiator than the customer him-/herself. This is of key importance for communication with consumers and the creation of the brand identity brand online communities have served their purpose by carefully listening to fans' opinions. Cherishing the category of mutual trust and allowing active dialogue and the exchange of opinions and experiences, the online brand community of the Zara fashion brand has brought even more customers closer to itself by using the most efficient digital marketing tool.

\section{References}

1. AbdelFattah, M., Galal, D., Hassan, N., Elzanfaly, D. S., \&Tallent, G. (2017). A Sentiment Analysis Tool for Determining the Promotional Success of Fashion Images on Instagram. International Journal of Interactive Mobile Technologies, 11(2), 2-7. doi. org/10.3991/ijim.v11i2.6563

2. Ashley, C., \& Tuten, T. (2015). Creative strategies in social media marketing: An exploratory study of branded social content and consumer engagement. Psychology \& Marketing, 32(1), 15-27. doi. org/10.1002/mar.20761

3. Berman, A. (2017).How Zara Took Over The Industry Using Fast Fashion. Retrieved from Alex Berman YouTube Channel: https://www.youtube.com/ watch?v=18_gmYNCQ1g. Retrieved from https:// www.researchgate.net/publication/332216487_ Analysis_of_the_Keys_to_Zara's_Inditex_Successful_ Business_Model

4. Black, I., \& Veloutsou, C. (2017). Working consumers: Co-creation of brand identity, consumer identity and brand community identity. Journal of Business Research, 70 (January), 416-429. doi.org/10.1016/j. jbusres.2016.07.012

5. Bogićević Milikić, B., \& Ognjanov, G. (2019). Uloga internog marketinga u unapređenju posvećenosti organizaciji, Marketing, 50(2), 94-111. Retrieved from https://scindeks-clanci.ceon.rs/data/pdf/03543471/2019/0354-34711902094B.pdf

6. Cheney, G., \& Munshi, D. (2017). Globalization and Global Village. In The International Encyclopedia of Intercultural Communication, p. 7., Wiley Blackwell

7. Chunling, L. (2020). Analysis on the Marketing Strategy of Fast Fashion Brand Zara Based on 4C Theory, 4th International Conference on Economics, Management Engineering and Education Technology (ICEMEET 2020). Retrieved from https:// webofproceedings.org/proceedings_series/ESSP/ ICEMEET\%202020/ICEMEET20089.pdf

8. Constantinides, E. (2014). Foundations of social media marketing. Procedia-Social and behavioral sciences, 148, 25 August, 40-57. doi.org/10.1016/j. sbspro.2014.07.016

9. Dabrowski, D., \& Schivinski, B. (2016). The effect of social media communication on consumer perceptions of brands. Journal of marketing \& communication, 22(2): 189. Retrieved from https:// www.tandfonline.com/doi/abs/10.1080/13527266.201 3.871323

10. Dahana,W.D, Miwa, Y., \& Morisada, M.(2019). Linking lifestyle to customer lifetime value: An exploratory study in an online fashion retail market. Journal of Business Research, 99, (June), 319-331. doi. org/10.1016/j.jbusres.2019.02.049

11. De Valck, K., Van Bruggen, G. H., \&Wierenga, B. (2009). Virtual communities: A marketing perspective. Decision Support Systems, 47(3), 185-203. doi.org/10.1016/j.dss.2009.02.008

12. Edvardsson, B., Tronvoll, B., \& Gruber, T. (2011). Expanding understanding of service exchange and value co-creation: a social construction approach. Journal of the Academy of Marketing Science, 39(2), 327-339. doi.org/10.1007/s11747-010-0200-y

13. Gamboa, A. M., \& Goncalves, H. M. (2014). Customer loyalty through social networks: Lessons from Zara on Facebook. Business Horizons, 57(6), 709-717. doi.org/10.1016/j.bushor.2014.07.003

14. García-Lillo, F., Claver-Cortés, E., Marco-Lajara, B., \& Úbeda-García, M. (2017). Mapping the Intellectual Structure of Research on 'Born Global'Firms and INVs: A Citation/Co-citation Analysis. Management International Review, 57(4), 631-652. doi.org/10.1007/ s11575-016-0308-5.

15. Gautam, V., \&Sharma, V. (2017). The Mediating Role of Customer Relationship on the Social Media Marketing and Purchase Intention Relationship with Special Reference to Luxury Fashion Brands, Journal of Promotion Management. 0(0), 1-17. doi.org/10.1080 /10496491.2017.1323262

16. Gunawan, D.D., \&Huarng, K.H. (2015). Viral effects of social network and media on consumers' purchase intention. Journal of Business Research, 68(11), 22372241. doi.org/10.1016/j.jbusres.2015.06.004

17. Gyrd-Jones, R., \& Kornum. N. (2013). Managing the co-created brand: Value and cultural complementarity in online and offline multi-stakeholder ecosystems. Journal of Business Research, 66(9), 1484-1493. doi. org/10.1016/j.jbusres.2012.02.045

18. Hakala, H., Niemi, L., \& Kohtamäki, M. (2017). Online brand community practices and the construction of brand legitimacy. Marketing Theory, 17(4), 537-558. doi.org/10.1177/1470593117705695 
19. Heinonem, K. (2011). Consumer Activity in Social Media: Managerial Approaches to ConsumersSocial Media Behaviour, Journal of Consumer Behaviour, 10, 356-364. doi.org/10.1002/cb.376

20. Huseynov, F., Huseynov, Y.S., \&Ozkan, S. (2014). The influence of knowledge-based e-commerce product recommender agents on online consumer decision making, Information Development, 32(1), doi. org/10.1177/0266666914528929

21. Inditex official site. Retrieved from https://www. inditex.com/en/article?articleId=662520\&title=Indite $\mathrm{x}+$ exceeds+\%E2\%82\%AC1.1+billion+net+profit

22. Interbrand official site. Retrieved from https:// interbrand.com/best-global-brands/zara/

23. Jaworski, B. J. (2018).Introducing the Theory and Practice section, AMS Review, 8, 1-4, doi.org/10.1007/ s13162-018-0118-y

24. Jung, A.R. (2017). The influence of perceived ad relevance on social media advertising: An empirical examination of a mediating role of privacy concern. Computers in Human Behaviour, 70, 303-309. doi. org/10.1016/j.chb.2017.01.008

25. Karamian, H., Nadoushan, M. A., \& Nadoushan, A. A. (2015). Do Social Media

26. Marketing Activities Increase Brand Equity?, International Journal of Economy, Management and Social Sciences, 4(3), 362-365. Retrieved from https://www.semanticscholar.org/paper/ Do-Social-Media-Marketing-ActivitiesIncrease-Brand-Karamian-Nadoushan/ c8a9ab821df4ad02e954bc6302d913c82141c219

27. Khan, Z., Yang, Y.,Shafi, M., Yang, R. (2019). Role of Social Media Marketing Activities (SMMAs) in Apparel Brands Customer Response: A Moderated Mediation Analysis, Sustainability, 11(19), 5167; doi:10.3390/su11195167

28. Kim, Y., \& Wha Oh K. (2019). Which Consumer Associations Can Build a Sustainable Fashion Brand Image? Evidence from Fast Fashion Brands, Sustainability, 12, 1703; doi:10.3390/su12051703

29. Kornum, N., Gyrd-Jones, R., Al Zagir, N., \& Brandis, K. A. (2017). Interplay between intended brand identity and identities in a Nike related brand community: Co-existing synergies and tensions in a nested system. Journal of Business Research, 70, 432440. doi.org/10.1016/j.jbusres.2016.06.019

30. Kotler, P., \&Keller, K. (2011).Marketing Management: 14 th edition, Prentice Hall.

31. Kozinets, R. V. (2015). Netnography: Redefined (2nd ed.). London, UK: SAGE Publications Ltd.

32. Kraus, S., Niemand, T., Angelsberger, M., MasTur, A., \& Roig-Tierno, N. (2017). Antecedents of International Opportunity Recognition in Born Global Firms. Journal of Promotion Management, 23(3), 1-21. doi.org/10.1080/10496491.2017.1294869

33. Margarida, A., Gamboa, H., \& Martins G. (2014). Customer loyalty through social networks: Lessons from Zara on Facebook Author links open overlay panel,Business Horizons, 57(6), 709-717. doi. org/10.1016/j.bushor.2014.07.003

34. Marić, D., Kovač Žnideršić, R., Paskaš, N., Jevtić, J., \& Kanjuga, Z. (2017). Savremeni potrošač i elektronska interpersonalna komunikacija, Marketing, 48(3), 147155. Retrieved from https://issuu.com/maxnova/docs/ marketing-vol-48-no-3

35. Mayrhofer, U., \& Roederer, C. (2016). Zara: The international success of fast-moving fashion, PostPrint hal-01316137, HAL.

36. McCorkindale, T.,\& Distaso, M.W. (2013).The Power of Social Media and Its Influence on Corporate Reputation, The Handbook of Communication and Corporate Reputation.

37. Merz, M.A., He, Y., \& Vargo, S.L. (2009). The evolving brand logic: A service dominantlogic perspective. Journal of the Academy of Marketing Science, 37(3), 328-344. doi.org/10.1007/s11747-009-0143-3

38. Ognjanov, G. (2013). Integrisane marketinške komunikacije, Centar za izdavačku delatnost Ekonomskog fakulteta u Beogradu, 2. izdanje.

39. Popović Šević, N. (2019). Prodaja i menadžment prodaje, Visoka škola strukovnih studija za informacione tehnologije - ITS, 1. izdanje.

40. Popp, B.; Woratschek, H. (2016). Introducing branded communities in sport for building strong brand relations in social media. Sport Management Review, 19(2), 183-197. doi.org/10.1016/j.smr.2015.06.001

41. Ramaswamy, V., Ozcan, K. (2016). Brand value co-creation in a digitalized world: An integrative framework and research implications, International Journal of Research in Marketing, 33, 93-106, doi. org/10.1016/j.ijresmar.2015.07.001

42. Schlegelmilch, B. B. (2016).Segmenting Targeting and Positioning in Global Markets, Springer, Cham.

43. Schlossberg, M. (2015). Zara has one key advantage over Gap and J. Crew. Retrieved from https://retail. economictimes.indiatimes.com/news/apparelfashion/apparel/zara-has-one-key-advantage-overgap-and-j-crew/48998843

44. Singh, S., Sao, A., Nagare, T. B., \& Dharmarajan, A. (2017). Role of Social Media Marketing In Brand Building: The New Age Marketing Strategy. International Journal of Scientific Research, 5 (9). doi. org/10.36106/ijsr

45. Slijepčević, M. (2019). Modni marketing, savremene tendencije, HeraEdu, Edicija Best practices, Beograd, str. 302; 318.

46. Slijepčević, M., \& Radojević, I. (2018). Current trends in digital marketing communication, Faculty of Management, Belgrade Metropolitan University. Retrieved from http://symorg.fon. bg.ac.rs/proceedings/2018/papers/Digital\%20 Trends\%20in\%20Marketing\%20and\%20Strategic\%20 Communications.pdf 
47. Slijepčević, M., Radojević, I., \&Perić, N. (2020). Considering Modern Trends in Digital Marketing, Marketing, 51(1), 34-43. doi.org/ 10.5937/ markt2001034S

48. Tuten, T., \& Mintu-Wimsatt, A. (2018). Advancing our understanding of the theory and practice of social media marketing: Introduction to the special issue, Journal of Marketing Theory and Practice, 26(1-2), 1-3. doi.org/10.1080/10696679.2018.1393277

49. Yadav, M., \& Rahman, Z. (2017). Social media marketing: literature review and future research directions, International Journal of Business Information Systems, 25(2), 213-240. Retrieved from https://econpapers.repec.org/article/idsijbisy/ v_3a25_3ay_3a2017_3ai_3a2_3ap_3a213-240.htm

50. Zablocki, A., Schlegelmilch, B., \&Schant, E. (2017). Customer-Based Brand Equity in the Digital Age:
Development of a Theoretical Framework, Springer, Cham.

51. Van Roy, Rossetti, V., F., Piculescu, V. (2015). Consumer conditions in the EU: revised framework and empirical investigation, JRC Science and policy report.

52. Veljković, S., \& Panić, M. (2017). Strategije brendiranja u nižem cenovnom segmentu proizvoda - Analiza tržišta negaziranih voćnih sokova u Srbiji, Marketing, 48(3), 176-183. Retrieved from https:// www.academia.edu/43328208/Branding_strategies_ of_low_priced_products_Analysis_of_Serbian_Fruit_ Juice_Market

53. Veljković, S. (2018). Marketing usluga, Ekonomski fakultet.

54. Zara official Facebook. Retrieved from https://www. facebook.com/Zara

55. Zara official Pinterest. Retrieved from https://www. pinterest.com/zaraofficial/

\section{Abstract}

\section{Marketing usmeren na online brend zajednice na primeru kompanije Zara}

Nevenka Popović Šević, Anja Jeremić, Milica Slijepčević, Milena Ilić

U današnje vreme sveje brža ekspanzija u domenu tehnoloških dostignuća, a sa uvođenjem Interneta u našu svakodnevnicu došlo je do velikih promena u načinima povezivanja ljudi i načinima komunikacije. Ljudi su počeli da se povezuju online. Online zajednice nastale su kao mreža ljudi koji su putem specifičnih online medija okupljeni oko istih interesovanja, bilo privatnih ili poslovnih, stvarajući ogromnu platformu za razmenu informacija, iskustava i znanja koja prevazilazi sve geografske, društvene i vremenske barijere. Kao nova platforma za razmenu informacija, online zajednice takođe predstavljaju i novi kanal preko koga kompanije promovišu svoje poslovanje i svoje proizvode, i omogućavaju nove dodirne tačke sa kupcima, koji danas imaju sve veću moć, dostupnost i pristup informacijama. U radu će biti analiziran marketing usmeren na online zajednice potrošača na primeru kompanije Zara.

Key words: online brend zajednice, ponašanje potrošača, društveni mediji, modni brend, Zara.

\section{Kontakt:}

Nevenka Popović Šević, nevenka.popovic.sevic@fsu.edu.rs Univerzitet Privredna akademija u Novom Sadu, Fakultet savremenih umetnosti Svetozara Miletića 12, Beograd, Srbija

Anja Jeremić, anja12517@its.edu.rs Visoka škola strukovnih studija za informacione tehnologije, ITS - Beograd Savski nasip 7, Beograd, Srbija

Milica Slijepčević, milica.slijepcevic@metropolitan.ac.rs Fakultet za menadžment, Univerzitet Metropolitan, Tadeuša Košćuška 63, Belgrade, Serbia

Milena Ilić, milena.ilic@fsu.edu.rs Univerzitet Privredna akademija u Novom Sadu, Fakultet savremenih umetnosti Svetozara Miletića 12, Beograd, Srbija 